\title{
FIRST DETECTION OF CIRCOVIRUS-LIKE SEQUENCES IN AMPHIBIANS AND NOVEL PUTATIVE CIRCOVIRUSES IN FISHES
}

\author{
Zoltán László TARJÁn, Judit J. PÉNZES, Róza P. TÓTH and Mária BENKÖ* \\ Institute for Veterinary Medical Research, Centre for Agricultural Research, \\ Hungarian Academy of Sciences, P.O. Box 18, H-1581 Budapest, Hungary
}

(Received 18 September 2013; accepted 31 October 2013)

\begin{abstract}
The negative samples of a collection, established originally for seeking new adeno- and herpesviruses in lower vertebrates, were screened for the presence of circoviruses by a consensus nested PCR targeting the gene coding for the replication-associated protein. Six fish samples representing five species, namely asp (Aspius aspius), roach (Rutilus rutilus), common bream (Abramis brama), round goby (Neogobius melanostomus) and monkey goby (Neogobius fluviatilis), as well as three frog samples were found positive for circoviral DNA. Sequence analysis of the amplicons indicated the presence of three novel putative circo-like viruses and a circovirus in Hungarian fishes and one novel circovirus in a common toad (Bufo bufo), and another one in a dead and an alive specimen of green tree frog (Litoria caerulea), respectively. In phylogeny reconstruction, the putative bream circovirus clustered together with circoviruses discovered in other cyprinid fishes recently. Three other piscine circoviral sequences appeared closest to sequences derived from different environmental samples. Surprisingly, the nucleotide sequence derived from two fish samples (a bream and a monkey goby) proved to be from porcine circovirus 2 (PCV2), almost identical to a sequence detected in Sweden previously. This is the first report on the detection of PCV2 in fish and circoviral DNA in amphibian hosts.
\end{abstract}

Key words: Circovirus, fish, frog, nested PCR, phylogenetic analysis

Although the first recognised circoviral disease, namely the beak and feather disease of parrots has been known for a long time (Pass and Perry, 1984), the enormous diversity of circo-like viruses started to emerge rather recently. The continuous improvement in the detection methods has facilitated the discovery of numerous novel circo- and circo-like viruses during the past couple of years (Delwart and Li, 2012).

Circoviruses (CVs) have a small $(12-26.5 \mathrm{~nm})$, non-enveloped, icosahedral capsid which contains a circular single stranded (ss) DNA genome of about

*Corresponding author; E-mail: benko.maria@agrar.mta.hu; Phone: 0036 (1) 467-4083; Fax: 0036 (1) 467-4076 
1.7-2.3 kb. Generally, the genome is ambisense, and contains at least two genes (cap and rep) coding for the capsid (Cap) and for the replication-associated (Rep) proteins, respectively. Virus replication occurs in the nucleus of the host cell. Presently, the Circoviridae family is divided into two genera: Circovirus and Gyrovirus containing eleven and only one species, respectively (Biagini et al., 2011). Chicken anaemia virus, the only member of the Gyrovirus genus exhibits significant divergence from circoviruses, therefore some authors have even proposed its relocation into the family Anelloviridae (Hino and Prasetyo, 2009). A group of the newly detected circo-like viruses are also so different that their classification into a separate, new genus with the proposed name Cyclovirus within Circoviridae has been put forward ( $\mathrm{Li}$ et al., 2011). Members of the Circovirus genus have been demonstrated in representatives of different animal species worldwide, but their pathological role is not well understood in most of the cases (Delwart and Li, 2012). To date, only the bird CVs and the porcine circovirus type 2 (PCV2) could be connected unambiguously to specific diseases (Ellis et al., 1998; Woods and Latimer, 2000; Dán et al., 2003; Cságola et al., 2006). The main role of CVs in these animal diseases is thought to be by their immunosuppressive effect (Todd, 2000; Faurez et al., 2009).

Different metagenomic approaches and extended PCR screenings led to the discovery of circoviral and CV-like sequences mainly in environmental samples and sewage water (Blinkova et al., 2009; Rosario et al., 2009a, b). Recently, the PCR detection of novel CVs and proposed cycloviruses have been described in fish (Lörincz et al., 2011; Lörincz et al., 2012) and in evolutionarily more distant animals, such as some arthropods (Rosario et al., 2011), respectively. Yet there is no record about the observation of circo-like viruses in amphibians and reptiles. The present study reports the first detection of CVs in amphibians. Samples from several fish species from the family Cyprinidae and Gobiidae, as well as from frogs belonging to the Bufonidae and Hylidae families were found to contain circoviral rep-like DNA.

\section{Materials and methods}

\section{Sample processing and DNA purification}

A total of 236 fish (34 species), 9 amphibian (2 species), and 49 reptilian (4 species) samples, collected randomly from Hungarian freshwaters (Lakes Balaton, Velencei, Lázbérci, and the river Danube), or fish farms and pet shops, were screened. From the majority of the samples, the DNA extraction was made from the internal organs, and sometimes from multiple fry of the same fish species. From the carcasses, small pieces $(<100 \mathrm{mg})$ from the internal organs (liver, kidney, intestines, gonads) or the entire body were soaked in $1 \mathrm{ml}$ TE buffer (10 mM Tris-HCl, 1 mM EDTA, $\mathrm{pH} \mathrm{8.0)} \mathrm{in} \mathrm{microcentrifuge} \mathrm{tubes} \mathrm{and} \mathrm{minced} \mathrm{in}$ 
a TissueLyser LT disruption instrument (Qiagen, Germany) at $50 \mathrm{~Hz}$ for $10 \mathrm{~min}$. After homogenisation, the DNA extraction was made as described in detail by Dán et al. (2003). Besides the dead specimens, an excrement sample from a live green tree frog was also tested. From this, the DNA purification was carried out with the use of the E.Z.N.A. Stool DNA Kit (Omega Bio-Tek, USA) according to the manufacturer's instructions.

\section{PCR and sequencing}

Previously, our samples had been tested by PCR and found negative for the presence of adenoviruses and herpesviruses (unpublished results). For the detection of circoviral DNA, a broad-spectrum, consensus nested PCR, designed to amplify an approximately 350-bp fragment from the gene of the Rep protein of CVs, was used as described by Halami et al. (2008). The reactions were carried out in $25 \mu \mathrm{l}$ volume consisting of $16.125 \mu 1$ MilliQ water, $2.5 \mu 110 \mathrm{X}^{\text {Dream Taq }}{ }^{\mathrm{TM}}$ Green Buffer, $2.5 \mu \mathrm{l}(25 \mathrm{mM}) \mathrm{MgCl}_{2}$ solution, $0.75 \mu \mathrm{l}(10 \mathrm{mM}) \mathrm{dNTP}$ solution (Bioline, UK), $1 \mu \mathrm{l}(10 \mu \mathrm{M})$ from each (forward and reverse) primers, $0.125 \mu 1$ Dream Taq ${ }^{\mathrm{TM}}$ DNA polymerase enzyme (Fermentas, Lithuania), and $1 \mu 1$ sample DNA solution. The reaction mixture of the second round of PCR (with the inner primers) contained $15.125 \mu \mathrm{l}$ MilliQ water and $2 \mu \mathrm{l}$ target DNA (reaction mixture from the first round). The PCRs were run in a TPersonal thermocycler (Biometra, Germany) with the optimised programs each consisting of 45 cycles as recommended by Halami et al. (2008). The PCR products were checked by electrophoresis in $1 \%$ agarose gel, then purified by using the MEGAquick$\operatorname{spin}^{\mathrm{TM}}$ Kit (iNtRON Biotechnology, Korea) according to the manufacturer's recommendation. Direct sequencing of each product on both strands was performed with the BigDye ${ }^{\mathrm{TM}}$ Terminator v3.1 Cycle Sequencing Kit (Life Technologies, USA) using the inner consensus PCR primers $(4 \mu \mathrm{M})$. The sequencing reactions were resolved on an ABI Prism 3100 Genetic Analyzer (Applied Biosystems, USA) from a commercial supplier.

\section{Phylogenetic analysis}

The nucleotide (nt) sequence data were handled as described in detail elsewhere (Doszpoly et al., 2013). The partial sequences obtained from the rep gene were compared with their counterparts available in the GenBank using the BlastN and BlastX algorithms provided at the NCBI website (http://www.ncbi.nlm. nih.gov/). From the exceptionally rich choice of circo- and circo-like viruses, those were selected for inclusion in the phylogeny inference, which gave the highest scores with our sequences in the BlastX applications. The deduced amino acid (aa) sequences were aligned by the ClustalW programme in the MEGA5 software (Tamura et al., 2011) using Blosum protein weight matrix and the following parameters: gap opening penalty: 35 , gap extension penalty: 0.75 (pairwise 
alignment) and gap opening penalty: 15, gap extension penalty: 0.3 (multiple alignment) with $25 \%$ delay divergent cutoff. Neighbour-joining analysis was performed using the JTT aa substitution model. The topology of the phylogenetic tree was tested by bootstrap analysis with 1000 replications.

\section{Results}

\section{PCR and sequencing}

Six piscine and 3 amphibian samples, representing roughly $3 \%$ and $30 \%$ prevalence, respectively, were positive for circoviral rep-like DNA, whereas every reptilian sample was found to be negative. To our surprise, two of the 6 positive fish samples, namely one from a common bream (Abramis brama) and another from a monkey goby (Neogobius fluviatilis) shared 100\% and 99\% nucleotide sequence identity, respectively, with a PCV2 detected in pigs in Sweden in 1993 (Timmusk et al., 2008). Each of the other four sequences derived from the remaining positive fish samples were unique. Among these, a common bream sample contained a rep sequence most closely related to that of the barbel CVs (Lörincz et al., 2011), whereas in the samples from three other fish species, namely a roach (Rutilus rutilus), an asp (Aspius aspius) and a round goby (Neogobius melanostomus), further three novel rep sequences were detected. Among the amphibian samples, a putative new CV, resembling most the European catfish CV, published recently (Lörincz et al., 2012), was detected in the carcass of a common toad (Bufo bufo). In case of the green tree frog (Litoria caerulea) samples, we detected identical nucleotide sequences which imply the possible presence of the same, novel $\mathrm{CV}$ in a dead and a live animal.

As Table 1 presents, the newly detected rep-like sequences showed slight divergence in size (ranging between 292 and $322 \mathrm{nt}$ ), whereas their base composition ranged from equilibrated to moderately biased toward A+T (with $38.8 \%$ $\mathrm{G}+\mathrm{C}$ in the round goby sample). Interestingly, almost identical PCV2 sequences, differing merely in three bases and in two aa, were obtained from fishes belonging to two different (Cyprinidae and Gobiidae) families.

The new putative rep sequences were submitted to the GenBank and assigned to accession numbers from KF358277 to KF358282.

\section{Phylogenetic analysis}

After having removed the primer sequences, we made alignments from the deduced aa sequences of the PCR products with the corresponding region of 27 circoviral Rep proteins retrieved from the GenBank. The final alignment encompassed 91 amino acids. The phylogenetic tree inferred from neighbour-joining analysis is shown in Fig. 1. Three novel sequences, detected in one bream, in the 
common toad and in two green tree frogs, appeared clearly among members of the Circovirus genus. More specifically, the putative bream CV resembled most the two barbel circoviruses (BaCV1 and 2) reported from Hungary (Lörincz et al., 2011), whereas the sequence derived from the common toad seemed to be monophyletic with the European catfish circovirus (CfCV) also described by Hungarian researchers more recently (Lörincz et al., 2012). Interestingly, the putative CV supposedly present in the dead and live specimens of captive green tree frogs clustered closest to the branch of the bird CVs, although the node support (75) calculated by bootstrap analysis was not very strong. The sequences amplified from the round goby, asp and roach appeared within the clade of the so-called sewage associated CVs and CV-like viruses (Fig. 1).

\section{Discussion}

By PCR screening of almost 300 samples, collected from fishes and other poikilotherm vertebrates, four novel putative piscine circoviral sequences were obtained. Further two novel sequences of apparently circoviral origin were detected, for the very first time, in amphibians of two distant species, namely in a native common toad found dead in its natural habitat close to the lake Lázbérci, and in two (a dead and a live) individuals of captive-bred green tree frogs, originally natives to Australia. Additionally, also for the very first time, we report the detection of PCV2 rep sequences in two fishes (a common bream and a monkey goby) wild-caught in the river Danube.

Our results are in good agreement with those published recently with reports about the discovery of newer circo- and circo-like viruses in an immense number of samples. Some 15 years ago, the chapter on Circoviridae in the veterinary virology textbook had stated that these viruses occur only in birds of different species and in swine causing usually well-circumscribed pathologic entities such as psittacine beak and feather disease, chicken anaemia, pigeon circoviral disease, or postweaning multisystemic wasting syndrome (PMWS) of pigs (Varga et al., 1999). Initially, the number of avian CVs started to rise rapidly (Smyth and Carroll, 1995; Woods and Latimer, 2000; Todd, 2004; Todd et al., 2007; Halami et al., 2008), then numerous novel CV-like sequences have been reported from various vertebrate and invertebrate animals (Li et al., 2011; Rosario et al., 2011; Dayaram et al., 2013b), meat products (Li et al., 2010) and environmental samples (Blinkova et al., 2009; Rosario et al., 2009b). The explosion-like sharp increase in the number of recognised putative circo-like viruses as well as in the number of animal species identified as potential hosts was somewhat unexpected, and the evaluation of the pathological significance of infection by, or simply the presence of, these viruses will require thorough investigations in the future. 


\section{Table 1}

Geographical and host origin of samples found positive for the presence of circoviral or circovirus-like DNA. The size, coding capacity and $\mathrm{G}+\mathrm{C}$ content of the rep gene fragments amplified by PCR are also shown

\begin{tabular}{|c|c|c|c|}
\hline Geographical and host origin of the positive samples & $\begin{array}{l}\text { PCR product size } \\
\text { without primers } \\
\quad(\mathrm{bp})\end{array}$ & $\begin{array}{l}\text { Length of the deduced amino } \\
\text { acid sequence } \\
\text { (aa) }\end{array}$ & $\begin{array}{c}\mathrm{G}+\mathrm{C} \text { content } \\
(\%)\end{array}$ \\
\hline $\begin{array}{l}\text { Common bream (Abramis brama) } \\
\text { from the river Danube in Budapest region }\end{array}$ & 307 & 102 & 47.2 \\
\hline $\begin{array}{l}\text { Roach (Rutilus rutilus) } \\
\text { from Lake Balaton }\end{array}$ & 307 & 102 & 57.9 \\
\hline $\begin{array}{l}\text { Asp (Aspius aspius) } \\
\text { from the river Danube in Budapest region }\end{array}$ & 292 & 97 & 47.3 \\
\hline $\begin{array}{l}\text { Round goby (Neogobius melanostomus) } \\
\text { from the river Danube in Budapest region }\end{array}$ & 322 & 107 & 38.8 \\
\hline $\begin{array}{l}\text { Common bream (Abramis brama })^{*} \\
\text { from the river Danube in Budapest region }\end{array}$ & 307 & 102 & 46.3 \\
\hline $\begin{array}{l}\text { Monkey goby (Neogobius fluviatilis) } \\
\text { from the river Danube in Budapest region }\end{array}$ & 306 & 101 & 45.1 \\
\hline $\begin{array}{l}\text { Common toad (Bufo bufo) } \\
\text { from the Lázbérc Reservoir (Northern Hungary) }\end{array}$ & 307 & 102 & 48.5 \\
\hline $\begin{array}{l}\text { Green tree frog (Litoria caerulea) captive-bred } \\
\text { from pet shop }\end{array}$ & 310 & 103 & 47.5 \\
\hline
\end{tabular}




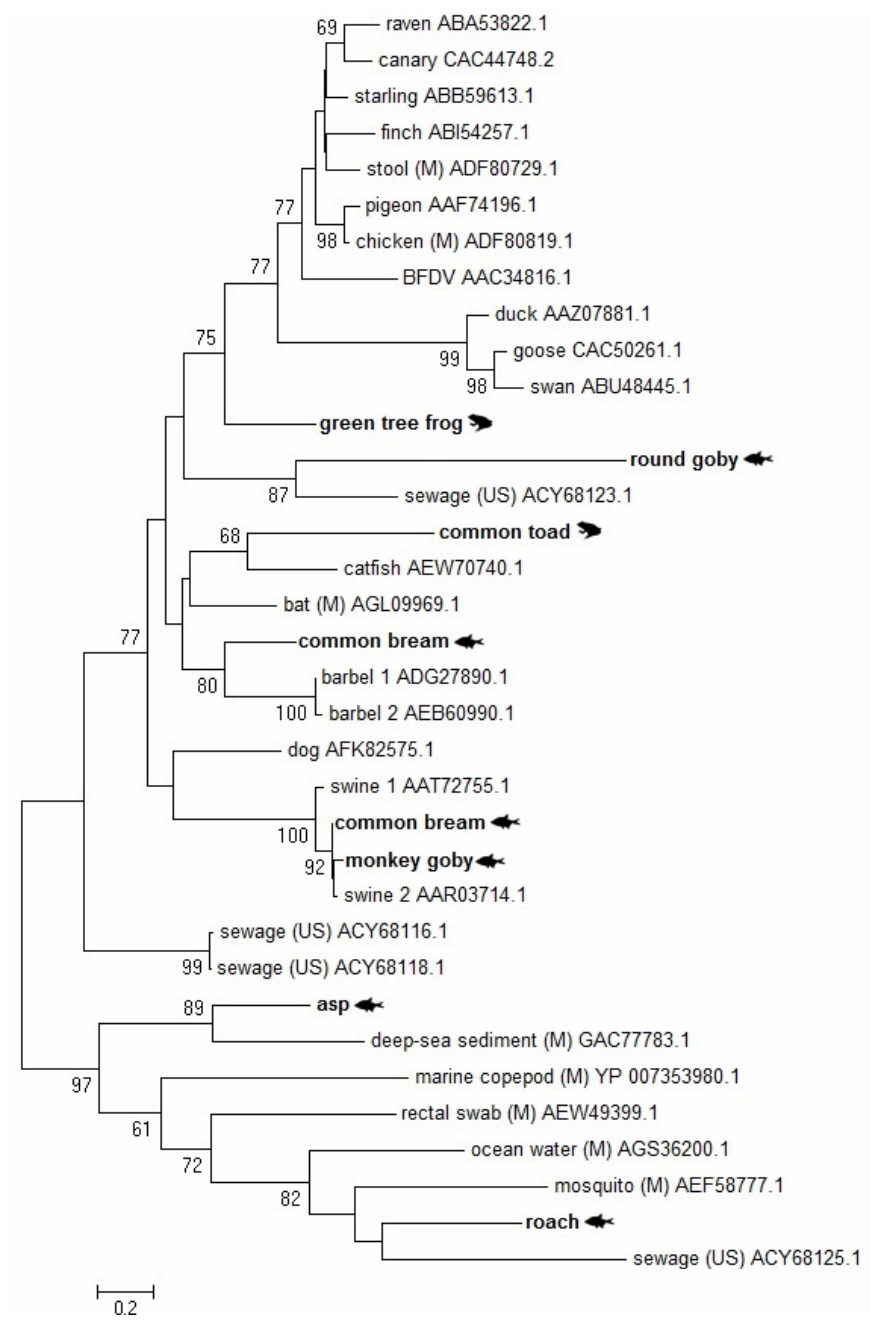

Fig. 1. Phylogeny reconstruction based on neighbour-joining analysis of partial amino acid sequences of the replication-associated protein from different circoviruses. The viruses are marked

with their host name or isolation source and type number of the virus when it is applicable. The newly determined sequences are printed in bold. Bootstrap values higher than $60 \%$ are shown near the bifurcations. The scale represents $20 \%$ estimated genetic divergence between sequences.

Circovirus-like sequences originating from metagenome screening are marked with (M). US $=$ untreated sewage water

Nonetheless, our findings further widened, with the amphibians, the spectrum of vertebrates that are known to carry circoviral rep-like DNA sequences. We also confirmed the utility and powerful performance of the nested PCR method elaborated by Halami et al. (2008) for the detection of CVs and other yet unknown small circular ssDNA viruses. Of course, our results have to be handled 
with appropriate care. The newly demonstrated putative viruses need further confirmation preferably by a full genome sequence analysis. Acquisition of the missing genome parts by an inverse PCR is already in progress. In a most recent paper, Hungarian authors have described the detection of circoviral rep sequences in two additional cyprinid fishes (Fehér et al., 2013). As the authors were unable to amplify the entire genome, they have concluded that in one case at least, the rep gene fragment was obtained by PCR not from viral particles but most probably from the fish chromosome where a virus-like DNA might have been integrated. The sequence of their PCR product indicated several mutations resulting in a truncated Rep protein. This has been taken as a further proof for the non-functional nature of the PCR-detected DNA (Fehér et al., 2013). In our survey, every PCR product contained intact ORF (without frame shifts or stop codons), which makes us assume that we amplified the rep-like fragments from actual viral genomes.

Although the possibility of transmission of PCV2 to non-porcine hosts has been published before (Lörincz et al., 2010; Deng et al., 2013), the detection of PCV2 sequences in the specimens of two fish species should be considered as the most surprising finding from the veterinary point of view. In these cases, just as in the case of every other newly detected putative $\mathrm{CV}$, we cannot decide with certainty if we detected an active viral infection, or merely the presence of a 'passenger' virus carried by the water. Every sample contained intestines or other parts from the digestive tract, and the applied PCR method provides enough sensitivity to detect viral DNA in such cases, too. The theoretical possibility of a laboratory cross-contamination could be excluded doubly. Firstly, nobody ever worked with PCV2 at all in our laboratory, and a duck CV was used as positive control. Secondly, the PCV2 sequences differed from each other and also from all porcine CV sequences described in Hungary previously. One of them was identical to, while the other only slightly divergent from, a PCV2 sequence (GenBank Accession No.: EU386606.1) reported from Sweden in 2008. Nonetheless, should this be an active infection in the fish or (more probably) just a passive carrier status, our finding has some veterinary relevance, as it discloses for the first time the potential mediator role of aquatic animals and/or natural waters in spreading PCV2 infection. It might be interesting to add, that both fish, that were found to carry PCV2 rep sequences, were caught, though on different occasions, in the north Budapest region of the Danube, not far from a place where a slaughterhouse for pigs had been functioning for several decades. In a very recent report, the unexpected detection of starling circovirus genomes has been described in molluscs in New Zealand. These authors also assumed a contamination from the water (Dayaram et al., 2013a).

As mentioned before, the pathogenic role of these small, circular ssDNA viruses is not well understood. Most recently, novel members of the Gyrovirus genus have been discovered in diseased chicken (Rijsewijk et al., 2011), but also in human faeces (Phan et al., 2012) and in healthy blood donors as well (Biagini et al., 2013a). The positive fish samples examined in our survey originated from 
apparently healthy individuals. The common toad was found dead but no visible macroscopic lesions were found. More interestingly, one of the positive green tree frogs died without any alarming signs, but its companion with the positive stool sample, kept in the same terrarium, is still healthy and alive.

The results of phylogeny calculations did not reflect readily a tight hostvirus association, as it can be seen in case of the large dsDNA viruses (Doszpoly et al., 2013). The only independent, clearly monophyletic group is that of the avian CVs within the genus Circovirus, whereas in the other clusters, a seemingly random mixing of the putative hosts can be observed. The firstly recognised fish CVs have also appeared in one common clade though with a very weak (36) node support (Fehér et al., 2013). Inclusion of our fish and frog circoviral Rep sequences rearranged this tree topology. The putative CV from the green tree frog clustered closest to the group of avian CVs but obviously representing a novel lineage, whereas the Rep sequence derived from the common toad appeared as a sister branch to that of the CfCV (Fig. 1). On the other hand, the putative $\mathrm{CV}$ detected in the common bream clustered with the CVs of the other cyprinid fish. The bootstrap values belonging to several branches were rather low; however, these ambiguities cannot be resolved unequivocally most likely due to the poor taxon sampling at the moment.

The prevailing hypothesis on the origin of $\mathrm{CVs}$ assumes a connection to plant-infecting nanoviruses followed by host-switching to vertebrate animals and subsequent recombination events (Gibbs and Weiller, 1999; Delwart and Li, 2012). It seems that the spectrum of potential hosts of small circular ssDNA viruses is much larger than it had been thought originally (Dayaram et al., 2013a, 2013b; Padilla-Rodriguez et al., 2013). This might have an effect on the taxonomical repartition of the Circoviridae family. A pending ICTV proposal suggests that the Gyrovirus genus should be moved to the family Anelloviridae indeed and at least one new genus Cyclovirus should be established within the Circoviridae (Biagini et al., 2013b). However, as it can be deduced also from our phylogeny inference, the existence of several additional larger clades that likely will merit genus-level demarcation within the Circoviridae family can be foreseen. The continuation of targeted screening of vertebrate animals will probably result in the recognition of circo-like viruses in reptiles as well. If we consider the number of extant species of fishes and of the recently discovered arthropod hosts, the existence of hundreds of novel small circular ssDNA viruses is expectable.

\section{Acknowledgements}

The financial support provided by the Hungarian Scientific Research Fund (Grant OTKA K100163) is greatly appreciated. Miss R. P. T. is an undergraduate student in biology at the Eötvös Loránd University (ELTE), Budapest. Special thanks are due to Ádám Dán for his help and for sharing his useful ideas with us. 


\section{References}

Biagini, P., Bédarida, S., Touinssi, M., Galicher, V. and de Micco, P. (2013a): Gyrovirus in healthy blood donors, France. Emerg. Infect. Dis. 19, 1014-1015.

Biagini, P., Bendinelli, M., Hino, S., Kakkola, L., Mankertz, A., Niel, C., Okamoto, H., Raidal, S., Teo, C. G. and Todd, D. (2011): Circoviridae. In: King, A. M. Q., Adams, M. J., Carstens, E. B. and Lefkowitz, E. (eds) Virus Taxonomy: Ninth Report of the International Committee on Taxonomy of Viruses. Elsevier/Academic Press, London. pp. 343-349.

Biagini, P., Breitbart, M., Delwart, E., Segales, J., Todd, D. and Varsani, A. (2013b): Restructuring and expansion of the family Circoviridae. Proposal for the International Committee on Taxonomy of Viruses. 2013.005a-eV. http://talk.ictvonline.org/files/proposals/taxonomy_ proposals_vertebrate $1 / \mathrm{m} /$ vert01/4593.aspx

Blinkova, O., Rosario, K., Li, L., Kapoor, A., Slikas, B., Bernardin, F., Breitbart, M. and Delwart, E. (2009): Frequent detection of highly diverse variants of cardiovirus, cosavirus, bocavirus, and circovirus in sewage samples collected in the United States. J. Clin. Microbiol. 47, 3507-3513.

Cságola, A., Kecskeméti, S., Kardos, G., Kiss, I. and Tuboly, T. (2006): Genetic characterization of type 2 porcine circoviruses detected in Hungarian wild boars. Arch. Virol. 151, 495-507.

Dán, Á., Molnár, T., Biksi, I., Glávits, R., Shaheim, M. and Harrach, B. (2003): Characterisation of Hungarian porcine circovirus 2 genomes associated with PMWS and PDNS cases. Acta Vet. Hung. 51, 551-562.

Dayaram, A., Goldstien, S., Zawar-Reza, P., Gomez, C., Harding, J. S. and Varsani, A. (2013a): Identification of starling circovirus in an estuarine mollusc (Amphibola crenata) in New Zealand using metagenomic approaches. Genome Announc. 1, doi:pii: e00278-13. 10.1128/ genomeA.00278-13.

Dayaram, A., Potter, K. A., Moline, A. B., Rosenstein, D. D., Marinov, M., Thomas, J. E., Breitbart, M., Rosario, K., Argüello-Astorga, G. R. and Varsani, A. (2013b): High global diversity of cycloviruses amongst dragonflies. J. Gen. Virol. 94, 1827-1840.

Delwart, E. and Li, L. (2012): Rapidly expanding genetic diversity and host range of the Circoviridae viral family and other Rep encoding small circular ssDNA genomes. Virus Res. 164, 114-121.

Deng, Z. B., Yuan, A. W., Luo, W., Wang, N. D., Gong, Q. L., Yu, X. L. and Xue, L. Q. (2013): Transmission of porcine circovirus type $2 \mathrm{~b}$ (PCV2b) in Kunming mice. Acta Vet. Hung. 61, 234-243.

Doszpoly, A., Wellehan, Jr. J. F. X., Childress, A. L., Tarján, Z. L., Kovács, E. R., Harrach, B. and Benkő, M. (2013): Partial characterization of a new adenovirus lineage discovered in testudinoid turtles. Inf. Genet. Evol. 17, 106-112.

Ellis, J., Hassard, L., Clark, E., Hardling, J., Allan, G., Wilson, P., Strokappe, J., Martin, K., McNeilly, F., Meehan, B., Todd, D. and Haines, D. (1998): Isolation of circovirus from lesions of pigs with postweaning multisystemic wasting syndrome. Can. Vet. J. 39, 44-51.

Faurez, F., Daniel, D., Grasland, B. and Jestin, A. (2009): Replication of porcine circoviruses. Virol. J. 6, 60.

Fehér, E., Székely, C., Lőrincz, M., Cech, G., Tuboly, T., Singh, H. S., Bányai, K. and Farkas, S. L. (2013): Integrated circoviral rep-like sequences in the genome of cyprinid fish. Virus Genes (in press), DOI 10.1007/s11262-013-0928-9.

Gibbs, M. J. and Weiller, G. F. (1999): Evidence that a plant virus switched hosts to infect a vertebrate and then recombined with a vertebrate-infecting virus. Proc. Natl Acad. Sci. USA 96, 8022-8027.

Halami, M. Y., Nieper, H., Müller, H. and Johne, R. (2008): Detection of a novel circovirus in mute swans (Cygnus olor) by using nested broad-spectrum PCR. Virus Res. 132, 208-212.

Hino, S. and Prasetyo, A. A. (2009): Relationship of Torque teno virus to chicken anemia virus. Curr. Top. Microbiol. Immunol. 331, 117-130. 
Li, L., Kapoor, A., Slikas, B., Bamidele, O. S., Wang, C., Shaukat, S., Masroor, M. A., Wilson, M. L., Ndjango, J. B., Peeters, M., Gross-Camp, N. D., Muller, M. N., Hahn, B. H., Wolfe, N. D., Triki, H., Bartkus, J., Zaidi, S. Z. and Delwart, E. (2010): Multiple diverse circoviruses infect farm animals and are commonly found in human and chimpanzee feces. J. Virol. 84, $1674-1682$.

Li, L., Shan, T., Soji, O. B., Alam, M. M., Kunz, T. H., Zaidi, Z. and Delwart, E. (2011): Possible cross-species transmission of circoviruses and cycloviruses among farm animals. J. Gen. Virol. 92, 768-772.

Lörincz, M., Cságola, A., Biksi, I., Szeredi, L., Dán, A. and Tuboly, T. (2010): Detection of porcine circovirus in rodents - Short communication. Acta Vet. Hung. 58, 265-268.

Lörincz, M., Cságola, A., Farkas, S. L., Székely, C. and Tuboly, T. (2011): First detection and analysis of a fish circovirus. J. Gen. Virol. 92, 1817-1821.

Lőrincz, M., Dán, Á., Láng, M., Csaba, G., Tóth, G. Á., Székely, C., Cságola, A. and Tuboly, T. (2012): Novel circovirus in European catfish (Silurus glanis). Arch. Virol. 157, 1173-1176.

Padilla-Rodriguez, M., Rosario, K. and Breitbart, M. (2013): Novel cyclovirus discovered in the Florida woods cockroach Eurycotis floridana (Walker). Arch. Virol. 158, 1389-1392.

Pass, D. A. and Perry, R. A. (1984): The pathology of psittacine beak and feather disease. Aust. Vet. J. 61, 69-74.

Phan, T. G., Li, L., O’Ryan, M. G., Cortes, H., Mamani, N., Bonkoungou, I. J., Wang, C., Leutenegger, C. M. and Delwart, E. (2012): A third gyrovirus species in human faeces. J. Gen. Virol. 93, 1356-1361.

Rijsewijk, F. A., Dos Santos, H. F., Teixeira, T. F., Cibulski, S. P., Varela, A. P., Dezen, D., Franco, A. C. and Roehe, P. M. (2011): Discovery of a genome of a distant relative of chicken anemia virus reveals a new member of the genus Gyrovirus. Arch. Virol. 156, 1097-1100.

Rosario, K., Duffy, S. and Breitbart, M. (2009a): Diverse circovirus-like genome architectures revealed by environmental metagenomics. J. Gen. Virol. 90, 2418-2424.

Rosario, K., Marinov, M., Stainton, D., Kraberger, S., Wiltshire, E. J., Collings, D. A., Walters, M., Martin, D. P., Breitbart, M. and Varsani, A. (2011): Dragonfly cyclovirus, a novel single-stranded DNA virus discovered in dragonflies (Odonata: Anisoptera). J. Gen. Virol. 92, 1302-1308.

Rosario, K., Nilsson, C., Lim, Y. W., Ruan, Y. and Breitbart, M. (2009b): Metagenomic analysis of viruses in reclaimed water. Environ. Microbiol. 11, 2806-2820.

Smyth, J. A. and Carroll, B. P. (1995): Circovirus infection in European racing pigeons. Vet. Rec. 136, 173-174.

Tamura, K., Peterson, D., Peterson, N., Stecher, G., Nei, M. and Kumar, S. (2011): MEGA5: Molecular evolutionary genetics analysis using maximum likelihood, evolutionary distance, and maximum parsimony methods. Mol. Biol. Evol. 28, 2731-2739.

Timmusk, S., Wallgren, P., Brunborg, I. M., Wikström, F. H., Allan, G., Meehan, B., McMenamy, M., McNeilly, F., Fuxler, L., Belák, K., Põdersoo, D., Saar, T., Berg, M. and Fossum, C. (2008): Phylogenetic analysis of porcine circovirus type 2 (PCV2) pre- and post-epizootic postweaning multisystemic wasting syndrome (PMWS). Virus Genes 38, 509-520.

Todd, D. (2000): Circoviruses: immunosuppressive threats to avian species: a review. Avian Pathol. 29, 373-394.

Todd, D. (2004): Avian circovirus diseases: lessons for the study of PMWS. Vet. Microbiol. 98, $169-174$.

Todd, D., Scott, A. N., Fringuelli, E., Shivraprasad, H. L., Gavier-Widen, D. and Smyth, J. A. (2007): Molecular characterization of novel circoviruses from finch and gull. Avian Pathol. 36, 75-81.

Varga, J., Tuboly, S. and Mészáros, J. (1999): Diseases caused by circoviruses. In: Varga, J. (ed.) Veterinary Epizootiology II: Infectious Diseases of Farm Animals [in Hungarian]. Mezőgazda Kiadó, Budapest. pp. 287-290.

Woods, L. W. and Latimer, K. S. (2000): Circovirus infection of nonpsittacine birds. J. Avian Med. Surg. 14, 154-163. 